Acta Theriologica 40 (1): 45-51, 1995.

PL ISSN 0001-7851

\title{
Numbers of red deer in the Słowiński National Park, Poland
}

\author{
Ryszard DZIĘCIOŁOWSKI, Jacek GOSZCZYŃSKI, \\ Michał WASILEWSKI and Joanna BABIŃSKA-WERKA
}

Dzięciołowski R., Goszczyński J., Wasilewski M. and Babińska-Werka J. 1995 Numbers of red deer in the Słowiński National Park, Poland. Acta Theriologica 40: $45-51$.

Density of red deer Cervus elaphus Linnaeus, 1758 had been estimated on the area of the Słowiński National Park (Poland, at Baltic Sea shore) from 1990 until 1993. Four research techniques were used: (1) spring observations in open areas adjacent to forest tracts, (2) night observations in spot-lights, (3) sample drives, and (4) winter tracking in snow. It was found that the first two underestimate actual deer numbers. Density based on driving census amounts to ca $12 \mathrm{ind} / \mathrm{km}^{2}$ of forests and reeds. This high density was confirmed by results of winter tracking.

Warsaw Agricultural University, Department of Zoology and Wildlife Management, Rakowiecka 26/30, 02-528 Warszawa, Poland

Key words: Cervus elaphus, numbers, density estimate, Baltic Sea shore

\section{Introduction}

Opinions about excessive numbers of deer prevail mostly among foresters. On the other hand real estimates of density are lacking and harvest quota are identified arbitrarily to a large extent. This inclined us to try to estimate numbers of red deer in the area, in which ecological studies on their population were carried out by us (R. Dzięciołowski et al., in prep.). The purpose of our studies was to estimate red deer Cervus elaphus Linnaeus, 1758 density within the Słowiński National Park situated on the Baltic Sea coast of Poland so that we could compare morphological, condition and breeding parameters of this population with those of different densities. We wanted also to verify whether possible changes in numbers will be reflected in the studied by us ecological characteristics of the local populations, as e.g. age structure, sex ratio, use of space, migration pattern, etc. Due to the restricted funds available we tried to use simple methods, but these had to be either modified by us or completely substituted. 


\section{Study area}

Studies were carried out in the Słowiński National Park $\left(54^{\circ} 33^{\prime} \mathrm{N}, 17^{\circ} 46^{\prime} \mathrm{E}\right)$ situated on the Baltic Sea coast. The park is also listed as the World Biosphere Reserve. The area of park covers 18247 ha, out of which lakes constitute more than a half ( $9763 \mathrm{ha}$ ).

The maritime climate prevails with relatively cool and short summers and mild winters. Precipitation amounts to 600-650 mm/year with 64\% occuring from July until September.

Physiographic diversity is considerable. Forest tracts, meadows, dunes and reeds surrounding lakes are the most important habitats for the local red deer population. The landscape of SPN constitutes an interesting mosaics of the ecosystems mentioned. This landscape provides an interesting example of the interspersion of natural and anthropogeneous ecosystems typical for the fine-grained pattern of European landscapes.

Scots pine Pinus silvestris is the most important forest-forming tree species. Coastal pine forest (Empetro nigri-Pinetum) is a dominant forest association on the Łeba Bar. Deciduous forests play a minor role. They are represented by mesophilous relict beechwood in the Kluki Forest, alderwood (Carici elongatae-Alnetum) adjoining lakes, poor alluvial woodland (Circaeo-Alnetum) and willow shrubs (Myrico-Salicetum).

Community of ungulates in the park consists of: red $\operatorname{deer}$ C. elaphus, roe deer Capreolus capreolus, wild boar Sus scrofa, and moose Alces alces. The first three species are numerous, but moose is only transient. There are no big predators in the park. Sporadically stray domestic dogs can be met.

Forest tracts situated within the park are following: Kluki, Smołdzino, Smołdziński Las, Rowy, Rąbka and Żarnowska (Fig. 1). The southern portion of the Smołdzino forest tract has been disregarded in studies. Based on the field survey and identification of locations of animal concentrations, the following three categories of red deer habitats have been distinguished: forests ( $5028 \mathrm{ha}$ ), reeds and lakeshore shrubs (1178 ha), forest bogs, overgrown meadows, dunes grown with vegetation, etc. (847 ha). These habitats are used by deer during vegetation season both as daily cover and as feeding grounds. During winter the deer gather first of all in forests and on dunes. Reeds, shrubs adjoining lakes and bogs are during this season by far less attractive due to the raised water level and scanty food resources. Apart from food gained in diurnal mainstays, red deer feed on the adjoining meadows, pastures, and cultivated fields.

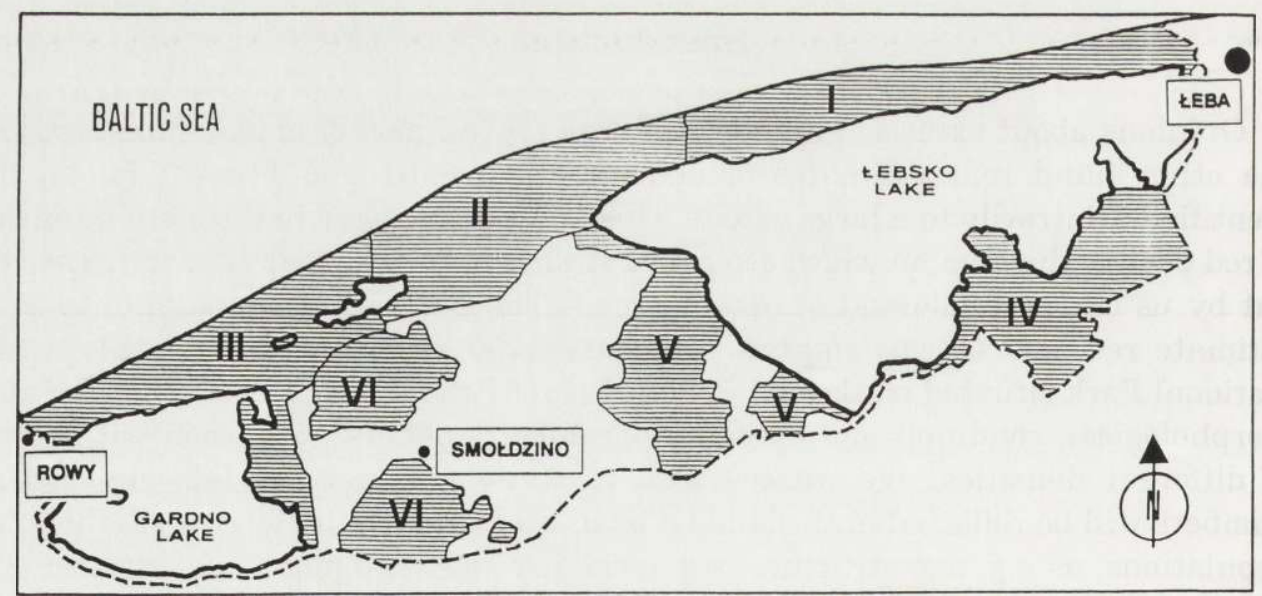

Fig. 1. Map of study area. Forest tracts: I - Rąbka, II - Smołdziński Las, III - Rowy, IV - Żarnowska, V - Kluki, VI - Smołdzino. 
During studies (1990-1993) the local red deer population was subjected to harvesting both by the park administration and by the neighbouring hunting clubs. Hunting season for stags and calves lasts from August 21 until February 28, while that for hinds - from September 1 until January 31. Beginning with 1991 numerous meadows within and close to the park have turned into wasteland, because fertilization, reclamation and, in numerous cases, grass-cutting were ceased.

\section{Census procedures}

Four basic techniques of census have been applied:

(1) Annual counts of red deer on open areas adjoining forests and reeds. Deer feeding on several great forest glades have also been counted. These counts were carried out at the end of April and beginning of May, when meadows and winter grain constituted attractive feeding grounds for red deer. Observers, located at the boundary of forests (or reeds) and open areas recorded the number of red deer and, if possible, their sex and age (yearlings versus adults). Observations would begin at 2 to 3 hours before dusk and conclude after darkness. Census was carried out on average during 3-4 days. It was assumed that deer appearing on the open constitute ca $80 \%$ of the studied population, because during the first census in spring of 1990 about $1 / 5$ of all the deer seen were those observed far from open locations (e.g. at Rąbka, close to sea positions of Rowy and Smołdziński Las) or staying in reeds. Deer inhabiting next to the sea habitats were counted during daylight, before the evening counts, by observing the area and watching from tops of dunes. Deer which did not leave reeds at night were registered from vantage points (towers and high seats) parallely with evening estimates.

(2) Nocturnal counts of red deer in the spotlight installed on a car. Observations were taken perpendicularly to the direction of a slowly driving car. Route of driving was predetermined prior to census in order to avoid double counts and to cover maximum area. Following preliminary testing of this technique (winter of 1993) we used it to verify data obtained during the evening observations of red deer (spring of 1993). Census with the use of spot-lighting was started around midnight and concluded shortly before dawn. The route covered amounted to ca $40 \mathrm{~km}$ and the area of open space on which counts were done was ca $22 \mathrm{~km}^{2}$.

(3) Red deer drives in selected compartments or their portions with the use of beaters and observers (Pucek et al. 1975). This technique was applied in 1993 in one of the forest tracts (Żarnowska) of the study area. Within the forest there were chosen eight compartments well representing it as to the age of their stands and site index. Their total area was 160 ha, that is ca $19.7 \%$ of the total forest area.

(4) Winter tracking. Taking advantage of the prevalence of snow cover in February of 1994 red deer tracking was performed in the study area. Tracks crossing the predetermined routes were counted. In case of tracks used by several red deer they were followed up to the spot were tracks dispersed and their number could be assessed. The total length of the transect amounted to $53 \mathrm{~km}$. The snow cover was about $12-20 \mathrm{~cm}$ thick during tracking. Results were presented in the form of an index showing the number of tracks per $1 \mathrm{~km}$ of route per day and night.

\section{Results and discussion}

During the first two springs following to the begining of studies in 1990 , a decline of the number of red deer appearing in fields and meadows was recorded. In 1993 their number increased but did not reach the level from the spring of 1990 (Table 1).

Changes in the numbers of red deer appearing on the fields may be interpreted as: (1) reflection of real numbers which were reduced (Table 1); (2) response of 
Table 1. Early spring censuses of red deer (in number of deer) appearing in open areas in the Słowiński National Park (ne - no estimates).

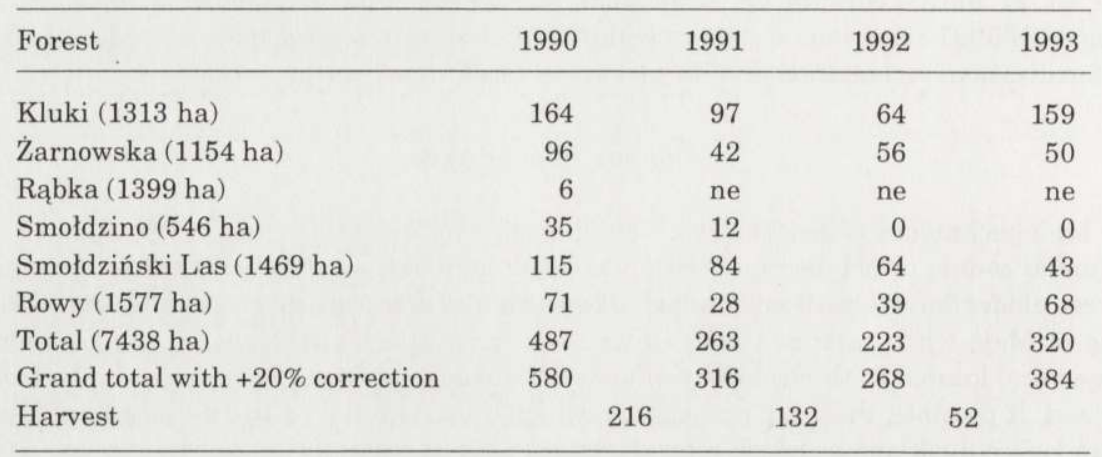

animals to strong hunting pressure during the first two seasons. This may result in avoiding of open areas or in alteration of activity rhythm, e.g. in appearing later in fields and meadows; (3) consequencies of alterations in food availability in open areas; (4) combination of factors mentioned above.

On the other hand, a thorough analysis of estimates of numbers, harvest and recruitment revealed that the decline of numbers of animals appearing at night on open areas cannot be directly related with culling. With the observed sex ratio (as 1:2 on the favour of females) and mean recruitment in 1990 ( 0.68 per female), the local population is growing by ca 260 individuals yearly. This value is more or less equal to the culling done in the area. During the following spring (1991) one could expect an unchanged number of deer, instead evening observations indicated a $46 \%$ decline of density (Table 1). On the other hand shooting alone could affect the behaviour of deer. That is why in order to find out whether deer had changed hours of appearing in fields and meadows, appraisals obtained by direct observations were compared with results of night censuses. Comparison was done in the same area and censuses were carried out directly (during the following night) after the evening counts. We thought that some animals appeared later on the open and that it would be possible to develop a correction that would account for this fact or to substitute evening counts by night census. Results obtained (259 red deer according to evening counts and 256 - according to spot light counts) indicate however the equal value of both techniques. It does not seem probable, therefore, that animals have changed rhythm of their activity.

As the next step we examined whether our previous assumption, that in the course of evening observations some $80 \%$ of the total population are recorded, was right. A complex assessment of red deer numbers was executed in 1993 in the Żarnowska Forest. It combined evening observations and drives. The former was to estimate deer density in a belt of reeds and lake-shore shrubs adjoining the forest. Between reeds and a forest there extends a strip of meadows. So, observers, situated along the forest borders could record animals leaving reeds and shrubs. 
The evaluated density amounted to 13.6 red deer $/ 1 \mathrm{~km}^{2}$ (11 adults/100 ha). Parallely to these estimates drives were carried out in the forest. Density was estimated at 9.6 individuals $/ 1 \mathrm{~km}^{2}$ ( 8.4 adults/100 ha). The number of adult deer present in the Żarnowska area (forest and reeds) was estimated at 105 individuals, while evening observations carried out two months earlier gave the result of 40 deer .

The above comparison shows univocally that evening observations reflect not so much actual numbers, as possible behavioural response of deer to the intensity of harvest and alterations in availability and attractiveness of food on the open areas. Economic collapse of meadow management enterprises, cessation of fertilization, maintenance and use of meadows, as well as dry springs of 1991 and 1992 coincided with changes in numbers of deer recorded in open areas. Our studies on the impact of deer upon the succession of forest stands in the park revealed an increase in damage to the young tree generations during 1991 and 1992 as compared to 1990 (W. Aulak, pers. comm.). This fact confirms a lesser intensity of penetration of open areas by the red deer.

Should the estimates from the Żarnowska Forest be accepted and extrapolated to the area of the park including forest tracts and reeds, then the number of adult red deer would attain the level of 624 individuals. With the sex ratio as 1:2 to advantage of females and average increment of 0.57 calf per female in 1993 , the number of red deer at the beginning of September attains 861 individuals (12.2 ind $/ 1 \mathrm{~km}^{2}$ ha of forest and reed area). These results indicate that probably in the course of the first estimate the number of "forest" deer was underestimated and this underestimate was later aggraviated, as deer appeared less numerously in fields and meadows. Because of that evening count cannot be recommended as a method of following changes in number dynamics.

Red deer tracking carried out in 1994 provided additional arguments in favour of the above mentioned thesis. The highest density of red deer was recorded in the Kluki Forest. Numbers of red deer hovever were very high also in the remaining forests (Table 2). It may be assumed that the number index (14 tracks $/ 1 \mathrm{~km}$ of

Table 2. Relative density of red deer in the Słowiński Natonal Park based on winter tracking (February of 1994).

\begin{tabular}{lccc}
\hline Forest & $\begin{array}{c}\text { Length of transect } \\
(\mathrm{km})\end{array}$ & $\begin{array}{c}\text { Number of red } \\
\text { deer tracks }\end{array}$ & $\begin{array}{c}\text { Number of tracks } / 1 \mathrm{~km}^{2} \\
\text { of transect per day }\end{array}$ \\
\hline Kluki & 7.5 & 219 & 29.2 \\
Żarnowska & 12.9 & 181 & 14.0 \\
Rąbka & 7.0 & 142 & 20.3 \\
Smołdzino & 3.7 & 36 & 9.7 \\
Smołdziński Las & 12.5 & 291 & 23.3 \\
Rowy & 9.5 & 127 & 13.4 \\
Total & 53.1 & 996 & 18.8 \\
\hline
\end{tabular}


route) in the Żarnowska Forest is equal to the density of 9.2 ind $/ 1 \mathrm{~km}^{2}$, i.e. such as obtained on the basis of counts in this forest during summer reduced by the cull during winter. The average for park index of 18.8 tracts $/ 1 \mathrm{~km}$ of route would be then equivalent to the density of $12.4 \mathrm{red}$ deer/1 $\mathrm{km}^{2}$. This is a very high density, but the index of track numbers in the Słowiński National Park considerably exceeds similar indices produced in other regions of eastern and north-eastern Poland (Table 3). It should be remembered that for example, the index of track numbers in the Białowieża National Park (ca $8 / \mathrm{km}$ ) is more or less equivalent to the density of ca 11 red deer/100 ha based on results of drives (Jędrzejewska et al. 1994). Unfortunately, we lack additional information as to the mean length of route made by red deer daily in the Słowiński National Park. It is possible that our deer are more mobile and this is why the recorded number of tracks is twice as big as that at Białowieża.

Table 3. Comparison of red deer density indices from various regions of Poland.

\begin{tabular}{|c|c|c|c|c|}
\hline Location & Time of studies & $\begin{array}{l}\text { Length } \\
\text { of transects } \\
(\mathrm{km})\end{array}$ & $\begin{array}{c}\text { Density } \\
\text { ( } n \text { of tracks/ } \\
\text { km/day) }\end{array}$ & Source \\
\hline Borki Forest & $\begin{array}{l}\text { 15-16 December } 1988 \\
15-18 \text { March } 1989\end{array}$ & 73.2 & 5.41 & $\begin{array}{l}\text { J. Goszczyński, } \\
\text { unpubl. }\end{array}$ \\
\hline Białowieża National Park & February-March 1987 & 59.2 & 7.66 & $\begin{array}{l}\text { Jędrzejewski et al. } \\
1992\end{array}$ \\
\hline Biebrza Valley & $1977-1980$ & 383.3 & 0.17 & Fedyk et al. 1984 \\
\hline Krynica Montane Forest & 1981-1991 & 1376.0 & 6.01 & Jamrozy 1994 \\
\hline Słowiński National Park & February 1994 & 53.1 & 18.80 & present studies \\
\hline
\end{tabular}

Results of both trackings and drives reveal that the red deer density found in the Słowinski National Park is among the highest in Poland. In other regions of the country red deer numbers assessed with the aid of drives do not reach normally the level of 4-5 ind/100 ha (Pucek et al. 1975, Krupka et al. 1986) and only in the Białowieża National Park is exceeds 10 ind/100 ha (Jędrzejewska et al. 1994).

Our studies indicate a great deceptiveness of some techniques (such as evening counts of deer appearing in fields or spot-light censuses) which assume a stable behaviour of animals appearing in the open. This portion of the population behaviour may be significantly modified by a hunting pressure or alteration in feeding attractiveness of non-forest habitats. The conclusion is that more labour-consuming and expensive techniques of censusing, e.g. drives, have to be applied. 


\section{References}

Fedyk S., Gębczyńska Z., Pucek M., Raczyński J. and Sikorski M. D. 1984. Winter penetration by mammals of different habitats in the Biebrza Valley. Acta Theriologica 29: 317-336.

Jamrozy G. 1994. [On snow...Results of 10 years long tracking of game in the Krynica forests]. Łowiec Polski 5: 14-15. [In Polish]

Jędrzejewska B., Okarma H., Jędrzejewski W. and Miłkowski L. 1994. Effects of exploitation and protection on forest structure, ungulate density and wolf predation in Białowieża Primeval Forest, Poland. Journal of Applied Ecology 31: 664-676.

Jędrzejewski W., Jędrzejewska B., Okarma H. and Ruprecht A. L. 1992. Wolf predation and snow cover as mortality factors in the ungulate community of the Białowieża National Park, Poland. Oecologia 90: 27-36.

Krupka J., Dziedzic R. and Drozd L. 1986. [Deer density estimates with particular reference to roe deer in various forest tracts]. Annales Universitatis Mariae Curie-Skłodowska, Sectio C, 4: 15-21. [In Polish]

Pucek Z., Bobek B., Łabudzki L., Miłkowski L., Morow K. and Tomek A. 1975. Estimates of density and number of ungulates. Polish ecological Studies 1: 121-135.

Received 17 June 1994, accepted 6 January 1995. 